\title{
Is there Any Relation between the Age of Patients and the Length of the Small Bowel? How Long is your Patient's Bowel?
}

\section{Sanguinetti $\mathrm{J}^{1,2 *}$, Barreiro $\mathrm{C}^{1}$, Voliovici $\mathrm{E}^{1}$, Bentancor $\mathrm{M}^{1}$, Montano $\mathrm{D}^{1}$, Anaulina Silveira ${ }^{3}$, Sonia Boudrandi ${ }^{4}$ and Enrique Barrios ${ }^{1}$}

${ }^{1}$ Physician, Clinical Surgery, Hospital Pasteur, South America

${ }^{2}$ Cantegril Sanatorium of Punta del Este, Uruguay

${ }^{3}$ Biostatistical BS, Hospital Pasteur, South America

${ }^{4}$ Physician, Quantitative Methods Department, Hospital Pasteur, South America

*Corresponding Author: Sanguinetti J, Physician, Clinical Surgery, Hospital Pasteur,

South America and Cantegril Sanatorium of Punta del Este , Uruguay

\section{Introduction}

The causes of bowel resections are very frequent. This can result in the onset of short bowel syndrome (SBS), clinical picture characterized by serious malabsorption. Diarrhea, malnutrition, weight loss, dehydration and electrolyte deficit require in some patients nutritional support for life [1-3].

SBS is defined by the 70 to $75 \%$ loss of the length of the small bowel or a bowel remnant less than $200 \mathrm{~cm}$, but how long is really the small bowel in the living patient? [1-5].

Authors describe that the human small bowel has lost length in its evolution, with dietary changes. The small bowel is a metabolically expensive tissue, the consumption of processed food has changed its physiology, pursuant to the already published by Aiello and Wheeler in 1995 in "expensive tissue hypothesis" [5]. We could not find trials relating the age of patients with the length of the small bowel [6-8]. Most anatomical and physiological descriptions state a length of 7, 8, and even 10 meters [7-12].

\section{Purposes of the Study}

- Measure the length of the small bowel in the living patient.

- Study the ratio between the age of the patient and the length of the small bowel.

- $\quad$ Study the ratio between weight, height, body mass index and bowel length.

\section{Material and Methods}

We analyzed 36 male patients; 29 white, 1 mixed race and 6 black, ranging from 16 to 78 years, treated at the Emergency Room of Hospital Pasteur, during the period of December, 2012 to No-
Received: July 31, 2020

Published: September 12, 2020

(C) All rights are reserved by Sanguinetti J., et al. vember, 2013, submitted to exploratory laparotomy due to urgent, non-inflammatory, non-obstructive pathology, mostly penetrating abdominal wounds, in hemodynamically stable patients, with normal preoperative paraclinical studies. Always with the same surgical team, with prior consent and information of all patients. This is made within the routine abdominal examination.

The measuring of the small bowel was made as part of this abdominal examination from the duodeno-jejunal angle to the ileocecal valve with a $75-\mathrm{cm}$ standard linen string $2-0$, this proceeding was made always in less than 5 minutes, always progressively in the small bowel, by the anti-mesenteric edge thereof. The study variables were age, weight, height, BMI, bowel length as well as ratios among these variables. P less than 0.05 .

\section{Statistical analysis}

- Quantitative Methods Department, Medicine Faculty

- Anaulina Silveira, Biostatistical BS.

- A 36-men analysis was carried out within the research work.

The following table shows the minimum and maximum values relating to age, weight and height variables, as well as the calculation of the average with its corresponding standard error (Table 1). The variable of weight is in $\mathrm{Kg}$ and height in $\mathrm{cm}$.

For the BMI, according to WHO, classified as follows: (Table 1)

Regarding race of males analyzed, it was observed that $80.6 \%$ of the cases (29 patients) were white, $16.7 \%$ ( 6 patients) were black and one patient was of mixed race. 


\begin{tabular}{|l|c|c|c|c|}
\hline & Minimum & Maximum & \multicolumn{2}{|c|}{ Average } \\
\hline & Stat. & Stat. & Stat. & Std. Error \\
\hline Age & 16.00 & 78.00 & 35.7778 & 3.16005 \\
\hline Weight & 56.00 & 90.00 & 71.4444 & 1.34486 \\
\hline Height & 150.00 & 185.00 & 171.8611 & 1.31786 \\
\hline
\end{tabular}

Table 1

\begin{tabular}{|l|c|c|}
\hline & Absolute F. & Rel. F. \% \\
\hline Normal & 21 & 58.3 \\
\hline Obese & 1 & 2.8 \\
\hline Overweight & 14 & 38.9 \\
\hline Total & 36 & 100.0 \\
\hline
\end{tabular}

Table 2

The following data correspond to a minimum, maximum, average $+/$ - EE for the length of the bowel $(\mathrm{cm})$.

\begin{tabular}{|l|c|c|c|c|}
\hline & Minimum & Maximum & \multicolumn{2}{|c|}{ Average } \\
\hline & Statistic & Statistic & Statistic & Std. Error \\
\hline Length_bowel & 345.00 & 700.00 & 499.0833 & 15.47047 \\
\hline
\end{tabular}

Table 3

Regarding the hypothesis that older the age, longer the intestine, Pearson correlation coefficient is calculated, $r$ gave 0.754 . This demonstrates a positive correlation between both variables, when one of them increases, the other one increases as well.

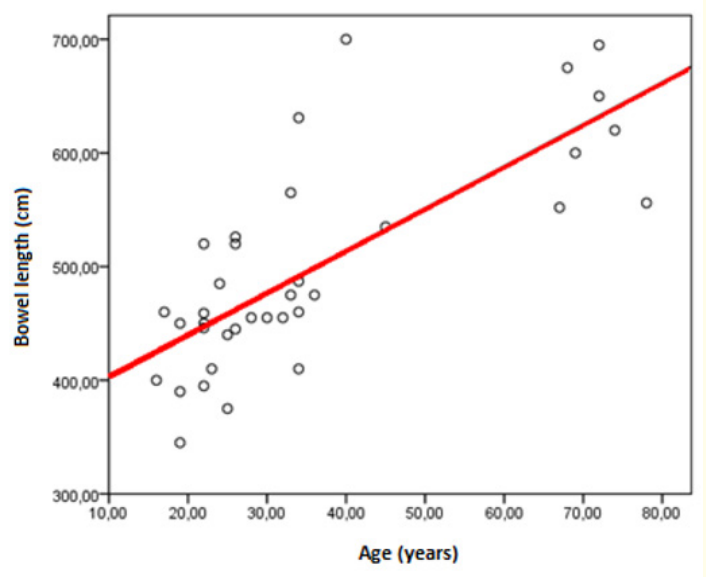

Figure 1

If we study the ratio between the height of the individual and the length of the bowel, we observe that no ratio is statistically stated. $r$ coefficient gave a value of -0.255 .

The following plot shows the no-ratio statement.

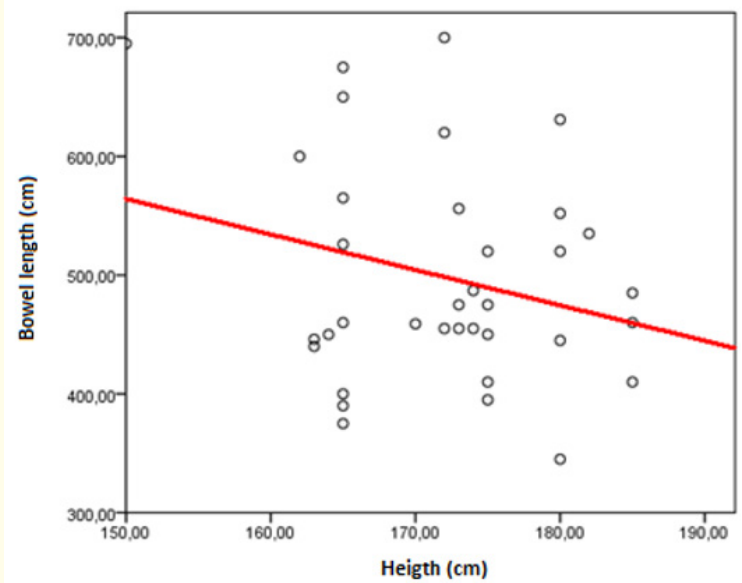

Figure 2

If we study the ratio between the weight of the individual and the length of the bowel, we observe that no ratio is statistically stated.

r coefficient gave a value of 0.407 .

The following plot shows the no-ratio statement, or what would be more correct, a very small positive ratio. After calculating the statistical test for studying the strength of this ratio, the same gave $p=0.079$, which is not significant.

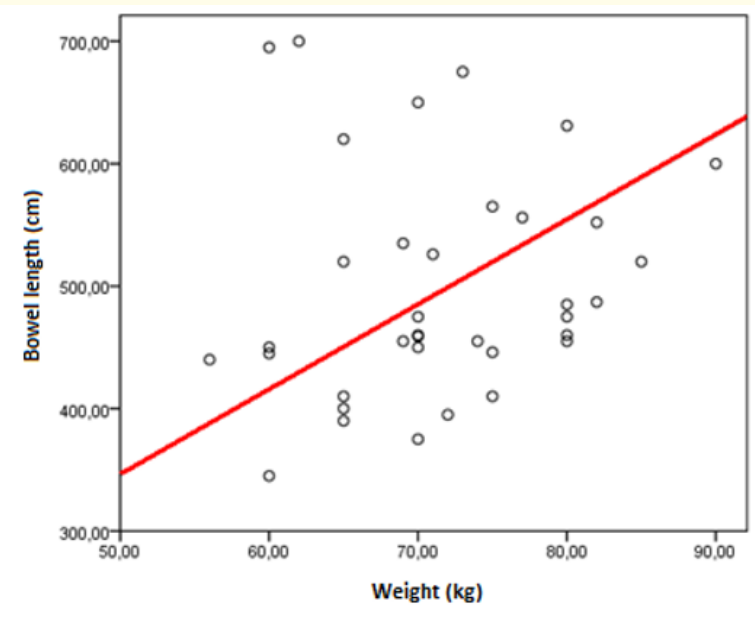

Figure 3 
We study the ratio between the IMC of the individual and the length of the bowel, we observe that no ratio is statistically stated.

r coefficient gave a value of 0.326 .

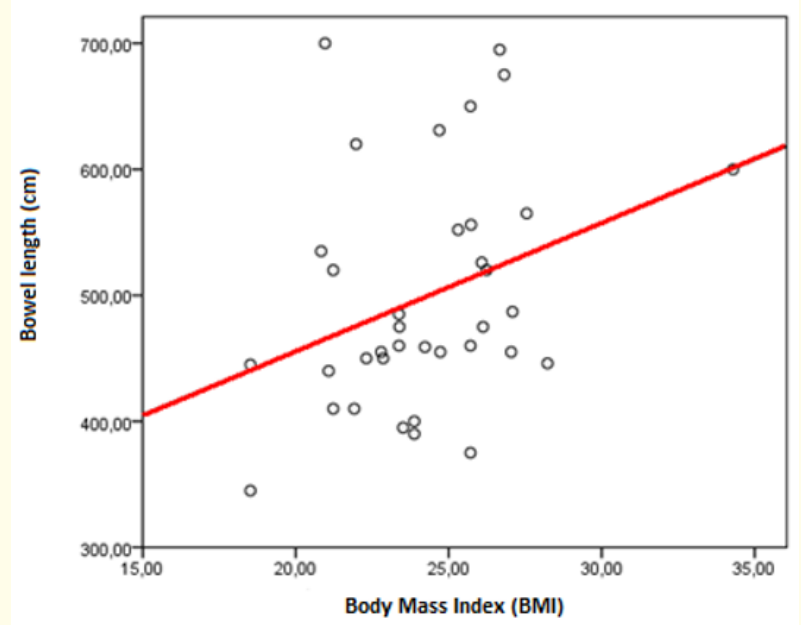

Figure 4

\section{Results}

Average length of the small bowel: $499.0833 \mathrm{~cm}$ with a range of $345.00 \mathrm{~cm}$ to $700.00 \mathrm{~cm}$.

Hypothesis: older the age, longer the intestine. Pearson correlation coefficient is calculated, $r$ gave 0.754 . This demonstrates a positive correlation between both variables, when one of them increases, the other one increases as well. p less than 0.05 .

There was no statistical significance between weight and height and the length of the bowel.

$r$ coefficient for height, value of 0.255 , $r$ coefficient for weight, value of 0.326 . Which are statistically no significant.

\section{Discussion}

We made a Descriptive-Clinical trial; this is novel in our environment since we did not find in the national literature any trial assessing the variables of our trial as well as its analysis in living and healthy patients, in our environment.

We made a literature research in the Medicine Faculty Library and the Uruguay Surgery Society Library, as well as research on the Internet databases.
Neither did we find trials studying the ratio between the bowel length and the age of patients, particularly in adults and in trials with in vivo measurements, with no extreme physiological modifications such as transplant procedures, explant procedures, or measurements in corpses or anatomical preparations [9,11-16].

Our trial measured the length of the small bowel and studied the ratios between this and the other variables only in men, consequently new trials including women groups, and greater amount of obese and overweight patients will be probably necessary for assessing these variables with the length of the bowel.

In later studies, patients from different social classes and with different type of feed shall be assessed, since in our trial most patients are in their normal weight range.

The detailed statistical analysis of the study of the age and bowel length variables as well as adding the ratio with BMI and other variables, make this trial a novel investigation and starting point for new trials.

On average, the small bowel measured $499.0833 \mathrm{~cm}$, less than what has been published in the classic literature [17-20]. This may be because the measurement in corpses when losing muscle tone would overestimate the length thereof.

\section{Conclusion}

- $\quad$ On average, the small bowel measured $499.0833 \mathrm{~cm}$.

- We proved that older the age, longer the small bowel.

- We did not find statistical ratio between weight or height and the length of the small bowel.

\section{Bibliography}

1. Fishbein TM. "Intestinal transplantation". The New England Journal of Medicine 361 (2009): 998-1008.

2. Mazariegos GV., et al. "Intestine transplantation in the United States, 1999-2008". American Journal of Transplantation 10 (2010): 1020-1034.

3. Underhill BML. "Intestinal length in man". British Medical Journal 4950 (1955): 1246-1246.

4. Nightingale JM and Lennard-Jones JE. "The short bowel syndrome: What's new and old?" Digestive Diseases 11 (1993): 12-31. 
5. Aiello C and Wheeler P. "The Expensive Tissue Hypotesis: The Brain and the Digestive system in Human and primate Evolution". Current Anthropology 36.2 (1995): 199-221.

6. Ahrens EH Jr., et al. "Measurement of the human intestinal length in vivo and some causes of variation". Gastroenterology 31 (1956): 274-284.

7. Siebert J. "Small-Intestine length in infants and children". American Journal of Diseases of Children 134 (1980): 593-595.

8. Backman L and Hallberg D. "Small-intestinal length. An intraoperative study in obesity". Acta Chirurgica Scandinavica 140 (1974): 57-63.

9. Touloukian RJ and Smith W. "Normal intestinal length in preterm infants". Journal of Pediatric Surgery 18 (1983): 720-723.

10. Fanucci A., et al. "Small bowel length measured by radiography”. Gastrointestinal Radiology 9 (1984): 349-351.

11. Reiquam CW., et al. "Normal and abnormal small bowel length: An analysis of 389 autopsy cases in infants and children". American Journal of Diseases of Children 109 (1965): 447-451.

12. Gray, Henry. La anatomía del cuerpo humano. Lea and Febinger (1985): 1478.

13. Avraham, Regina. Aparato Digestivo. Chelsea House (2000): 52.

14. Townsend., et al. Sabiston Textbook of Surgery, Elsevier (2004).

15. Thomson A., et al. "Small bowel review: Normal physiology, part 1". Digestive Diseases and Science 48.8 (2003): 1546-1564.

16. Thomson A., et al. "Small bowel review: Normal physiology, part 2". Digestive Diseases and Science 48.8 (2003): 1565-1581.

17. Testut L and Latarjet A. "Tratado de Anatomía Humana”. Spain. Salvat Editores (1982).

18. Rouvière H and Delmas A. "Anatomía Humana". Descriptiva, Topográfica y Funcional. 10th edition. Masson S.A. Barcelona (1999).

19. Latarjet M and Ruiz Liard A. "Anatomía Humana”. Argentina. Editorial Médica Panamericana (2004).

20. Testut L Jacob 0. "Tratado de Anatomía Topográfica con Aplicaciones Medicoquirúrgicas". Spain. Salvat Editores 2 (1981).

\section{Assets from publication with us}

- Prompt Acknowledgement after receiving the article

- Thorough Double blinded peer review

- Rapid Publication

- Issue of Publication Certificate

- High visibility of your Published work

Website: www.actascientific.com/

Submit Article: www.actascientific.com/submission.php

Email us: editor@actascientific.com

Contact us: +919182824667 